\title{
The East African Indian Ocean and the Security Challenges
}

\author{
ABDALLAH M. EL-NOFELY ${ }^{1 *} \&$ REHNA GUL ${ }^{2}$ \\ ZHONGNAN UNIVERSITY OF ECONOMICS AND LAW. \\ Postal Address:182\# Nanhu Avenue, East Lake High-tech Development Zone, Wuhan 430073, P.R.China \\ Website. http://english.zuel.edu.cn/ http://www.zuel.edu.cn/
}

November 14, 2020

\section{ACKNOWLEDGMENT}

We would also like to thank Mr. Leornad Jasuba Leo from the EAC office for his outstanding and constructive recommendations for this work.

\begin{abstract}
Piracy is an ancient phenomenon practiced in many parts of the world by states and individuals to represent political authority, economic control, military strength, vengeance, etc. Global trading routes, free passage, and a dangerous threat to regional and international stability have been adversely interrupted by these illegal activities. This article is intended to study the security impacts of Somali pirates on the Indian Ocean and its implications for integral economic growth.The article also revisits the historical piracy experience on the horn of Africa and East Africa and how the regional states and the international community have come together to suppress piracy.The article further suggests that foreign military intervention is not the ultimate solution to Somali piracy; however, political and diplomatic engagement can significantly impact water-down the severity of maritime criminal activities in the Indian Ocean beyond. Regional and international communities have decisively engaged in several military operations against Somali pirates. Their offshoots on land have not managed to eradicate these groups. The paper concludes that for the Indian Ocean to be safe, navigable, and a potential economic base that guarantees smooth transportation, fishing, and extraction of marine resources, the East African Indian Ocean countries must ensure security and political stability restored in Somalia.
\end{abstract}

Keywords: Piracy, global security, the East African Community, the Indian Ocean, piracy, maritime economy, maritime security

DOI: $10.7176 / \mathrm{JLPG} / 103-12$

Publication date: November $30^{\text {th }} 2020$

\section{Introduction}

The sea is the universal heritage that humankind has been using since the beginning of time to meet commercial, transportation, economic, scientific, and other developmental activities. Also is the main transport media through which global trade passes by, including medicines, food, fishing, charcoal, petroleum, and other essential items.

However, with the rise of piracy activities in the seas, especially in strategic passages such as the strait of Hormuz and Bab el Mandeb, security and free navigation and global trade have been disrupted. In this approach, Judge David Maraga concurred that "piracy is detrimental to the economy and can affect any state, so either state must punish the perpetrators."1 The pirates have been attacking ships mostly along Eyl and Mudug territorial waters in Punt-land Somalia.2

By realizing and comprehending the severity of piracy in territorial and high seas, the UNSC endorsed "a resolution 2383 in 2017 to renew the authorization of foreign naval forces off the coast of Somalia to combat piracy". Piracy knows no boundaries; it is a universal crime; that takes place involving different maritime jurisdictions; therefore, concerted attempts to crack down these criminal activities must be tackled in tandem by both regional and international communities.

\section{The Genesis of Piracy in the Indian Ocean}

The Indian Ocean is an important domain that connects the Atlantic and the Pacific Oceans due to the strategic location between Africa, the Middle East, and the Indian sub-continent has facilitated a smooth shipment of natural resources, food, medicines, and industrial raw materials.

Countries have the inalienable right to protect and defend statehood and sovereignty, including protecting persons, borders, and natural resources provided for in national constitutions and international laws.

The Somali people see the ocean as the pipeline for their livelihoods; therefore, obstructing them from

1. Kenya rules courts can try Somali pirates. (2012). BBC News. [online] October 18 Available at: https://www.bbc.com/news/world-africa-19992273.

2. Joshua, Ho. (2009). Piracy around the horn of Africa. Open Edition Journals. 
having no access to the sea resources means taking away their very survival.

The tendency of foreign-flagged vessels to take part in illegal fishing activities and dumping toxic and chemical wastes off the coast of Somalia has had adverse effects on the fishing industry and employment, and the environment.

Owing to the lack of viable solutions to address illegal foreign fishing, forced the Somalis to patrol and protect their territorial waters, which later on drew the attention of warlords and business people. With time, patrol operations turned violent resulted in piratical activities. Piracy inflicted a colossal blow to maritime security, global trade, and free navigation, hence alarming the regional and international communities to develop a permanent solution to address the crisis.

Any act of transgression that jeopardizes national sovereignty and international laws must not be tolerated because a single act of aggression against another country can have lasting repercussions that threaten stability, trade, and societal development in general. With Somalia, unlicensed fishing by foreign ships and the dumping of toxic waste has damaged marine biodiversity and bred piracy, a universal crime that the world is trying hard to suppress.

The wealth obtained through piracy and armed robbery is undoubtedly used to fund armed groups and buy weapons that subsequently expanded criminal networks and fueled civil unrest in Africa's horn region.1 The Somali pirate attacks target ships irrespective of their flag; however, larger cargo vessels like container ships and tankers remain vulnerable to pirate attacks due to their low speed and the cargo's economic value on board.2

The political malfunctioning and the death of the then Somalia president Sayyid Barre in 1991 had left the void for foreign ships to stem illicit activities in the Indian Ocean while the Somalis were into each other's throats. With no effective legal system, the country's political vacuum contributed to the lawlessness and breeding of criminal groups such as pirates. 3

\section{EAC Security Protocol}

The future economy's projection is so critical that East African countries have exponentially indulged in the diversification of the marine economic regime, research, and exploration of natural resources. The recent discovery of the gas field offshore Tanzania mainland is a clear manifestation of the ocean economy's shift. 4 The Indian Ocean must be free from any security threats that undermine free navigation and maritime economic integration to benefit from the oceanic wealth. The unprecedented rise of piracy activities does not end in Africa's horn alone; it spreads as far as to the east African countries of Kenya and Tanzania, while its aftermath echoed all along the East African "littoral and inland locked states."

Somalia is located geographically in North-East Africa and shares land and sea borders with Kenya, a significant EAC member country. Somali insurgent groups, both at sea and on land, have been the destabilizing factors that threatened Kenyan security. It must be born in mind that any act that threatens the EAC member country's security means the entire EAC is affected. Article 2(1) of the treaty establishes the EAC Protocol on Peace and Security calls on member States to closely cooperate in matters of peace and security and work with international and regional organizations to promote peace and security in the region."5

Likewise, article 2. (h) of the EAC on peace and security protocol reveals the need to "enhance the Partner States' capacity in combating terrorism and piracy at sea."6

Individual countries cannot defeat piracy in the Indian ocean; instead, a strong-based collective effort can ensure the prevalence of everlasting peace and security in East African waters and elsewhere in the Indian Ocean domain.

Article 3 of the East African Community's Treaty critically explains the EAC's objectives as "to promote peace, security, and stability within the Community and good neighborliness among the Partner States."

\section{Piracy and the International Legal Regime}

Piracy is described by the International Maritime Bureau (IMB) as "the act of boarding any vessel with intent to

1. Trends in African maritime security. African center for strategic studies, March 15, 2019.

2. United Nations Conference On Trade And Development, Maritime Piracy, An Overview Of Trends, Costs And Trade-Related Implications, 2014

3. Captain Larson, G. (2010). Somali Piracy: An age-old problem to a modern-day solution. Available from: www.hsdl.org.

4. Gongcheng Zhang; Giant discoveries of oil and gas fields in global deepwaters in the past 40 years and the prospect of exploration: 21 March 2019.

7. Protocol on Peace and Security. (n.d.). [online] Available at: http://eacgermany.org/wpcontent/uploads/2015/03/EAC-Protocol-On-Peace-And-Security.pdf

6. Ibid 
commit theft or any other crime, and with an intent or capacity to use force in furtherance of that act." 1

Resolution 1816, endorsed by the Security Council of the United Nations in 2008, allowed its member to take all appropriate steps under the UNCLOS 2 to counter the threat of piracy. Since then, several regional and international bodies have worked out legal and policy-related strategies to deter piracy Worldwide.

For piracy to constitute an offense, certain essential ingredients must be established by the court of law:-

(1). "the piratical act must be done against another ship or aircraft outside the jurisdiction of any State. The act must be illegal, amounting to violence, unlawful detention, or depredation" (2). "The act must have been committed for private ends by the crew or the passengers on board a private ship or aircraft, meaning the act committed without the State's approval" (3). The perpetrators carried out the act on their gains, whether financially or seeking revenge or any other reasons. 3

As mentioned earlier, piracy takes off the Somalia peninsula, mostly on the high seas in the Indian Ocean against foreign ships; arresting officers in most respects are foreigners. After the arrest, the perpetrators are brought to stand before the foreign court as well. The legal complexity surrounding piracy, especially dealing with Somali pirates, requires well-trained court officials on international criminal law; high-quality legal systems are needed to ensure that the defendant is prosecuted and punished according to international laws. For piracy to constitute an offense, certain essential ingredients must be established by the court of law;

1. "the piratical act must be done against another ship or aircraft outside the jurisdiction of any State. The act must be illegal, amounting to violence, unlawful detention, or depredation," 2. "The act must have been committed for private ends by the crew or the passengers on board a private ship or aircraft, meaning the act committed without the State's approval," 3. "The perpetrators carried out the act on their gains, whether financially or seeking revenge or any other reasons."4

Besides, the "Rome Convention of 2005 for the suppression of unlawful Acts of Violence against maritime navigation safety" describes and imposes an obligation on the states to take adequate steps to tackle piracy and other initiatives that suppress criminal activities in the sea. For example, "article 3 details that if a person or group of persons commit an offense deliberately with the guilt intent of seizing or taking control of a ship, in such a way force or intimidation is used, such an act amounts to piracy." 5

\section{Treatment of Pirates under the Lens of International Human Rights}

Despite the criminal acts against humanity committed by the pirates, it is the duty-bound responsibility of the countries that apprehend the culprits to ensure that they comply with the international laws and the universal declaration of human rights, also to provide the detainees with the legal help of the competent court. The host country must avoid subduing the perpetrators to torture, extrajudicial executions, or other punishments that would degrade their human rights.

"Articles 1 and 56 of the Universal Declaration of Human Rights stipulated that all human beings are born free and equal in dignity and rights and that no one is to be subjected to torture or inhuman, degrading treatment or punishment."7 So does the "International Convention on Civil and Political Right article 9 stipulates that no one should be subjected to arbitrary arrest or detention".8

Moreover, special consideration must be paid to minors who are involved in piracy-related activities. While in custodians, the children's human rights and welfare must be protected and respected at all times of their detention. Hence, every necessary caution is to be taken as accorded by the "1989 United Nations Convention on the Right of the Child" and also "the African Charter on the child's rights and welfare."9

1. https://www.icc-ccs.org/icc/imb

2 . United Nations Convention on the Law of the Sea. (n.d.). [online] Available at:https://www.un.org/Depts/los/convention_agreements/texts/unclos/unclos_e.pdf.

3. See UN. United Nations Convention on the Law of the Sea. article 101(a)(I) and 101(a)(ii) Available from: https://www.un.org/Depts/los/convention_agreements/texts/unclos/unclos_e.pdf.

4.See article 101(a)(I) and 101(a)(ii) of the United Nations Convention of the Law of the Sea

5. Sua Convention And 2005 Protocol Text Inventory Of International Nonproliferation Organizations And Regimes (C) Center For Nonproliferation Studies Convention For The Suppression Of Unlawful Acts Of Violence Against The Safety Of Maritime Navigation (Sua Convention). (n.d.). [online] Available at: http://oceansbeyondpiracy.org/sites/default/files/SUA_Convention_and_Protocol.pdf.

6. United Nations (1948). Universal declaration of human rights. Article-one[online] United Nations. Available at: https://www.un.org/en/universal-declaration-human-rights/.

7. Ibid. art. 5 of Universal declaration of human rights.

8. Front Line Defenders. (2020). Arbitrary detention of three human rights defenders. [online] Available at: https://www.frontlinedefenders.org/en/case/arbitrary-detention-three-human-rights-defenders [Accessed 14 Nov. 2020].

9. Au.int. (n.d.). African Charter on the Rights and Welfare of the Child $\mid$ African Union. [online] Available at: 


\section{Negative Impacts Of Piracy At Sea}

The height of armed robbery, hijackings, and ships' attacks in the East African shores and its territorial waters forced the regional and international communities to develop security and strategic intervention plans to secure the Indian Ocean from Somali pirates.

"The 2013 World Bank's report on piracy estimates that hijackings and maritime crimes in eastern African coasts cost the global economy approximately US\$ 18 billion annually by 2010".1 On the other side, Kenya, a neighbor and one of the victims of Somali pirates, estimates to have lost US\$ 300 million annually because of piracy and other maritime insecurities. 2 The pirates' severe threat has had a challenging impact on the shipping companies. The Somali pirates primarily targeted cargo ships, "chemical and oil vessels" that traverse the sea at low speed, thus becomes easy to attack and hijack. The insurance companies have to pay a considerable sum of money; in such a way, additional premiums have been imposed into a ransom payment scheme to compensate for the costs incurred due to piracy. Recently, many ships have started to take long routes to avoid the Somali pirates' ordeal, which has caused additional transportation and time costs.

\section{Measures Against Pirates In The Indian Ocean}

The world has witnessed a surge in maritime piracy, which has undermined both littoral and landlocked countries. Several countries have agreed to carry out a joint operation with the sole purpose of protecting free shipping, international commercial routes, and human trafficking, maritime environment.

Challenging the pirates and their offshoots in Somalia has always been cumbersome because of the extremist groups like Al Shabab tend to counter-attack the military offensive by the regional states, sometimes unleash havoc to innocent civilians.

\subsection{Djibouti Code of Conduct}

The Djibouti code of conduct 2009 appears to be the central pillar of maritime security cooperation on the Indian Ocean's side. The Djibouti Code of Conduct brought together several countries of the region from the Arabian Peninsula, Eastern, Southern, and Indian Ocean Africa to counter criminal activities at sea.3

There is an inextricable link between maritime security, maritime governance, and marine economy. 4 Criminals disguised as pirates impede the maximum utilization and exploitation of marine resources and commerce.

The 'DCC,' which bases on the western Indian Ocean and the Gulf of Aden, has, among other things, planned to curb illegal maritime activities that endanger the stability and the security of the region, such as marine terrorism and trafficking in human beings.

\subsection{Regional Piracy Prosecution Model}

The RPPM is a model set forth by the member states to combat maritime crimes and the Indian Ocean states, with a primary focus on criminal justice capacity building. The members' states have incorporated the model into their domestic legislation to enforce necessary measures to capture and prosecute pirates. Tanzania, Kenya, Mauritius, and Seychelles are among signatories to the model.

\subsection{AMISOM}

The African Union peacekeeping forces in Somalia AMISOM have played an instrumental role in eradicating terrorists and their hideouts on land and in the Indian Ocean. Combined task force 151, Interpol maritime piracy task, with resolution 1950(2010,), 1976(2011), 2020(2011).

The AMISOM's continuous operations targetting Al Shabab believed to have pushed the group to launch

https://au.int/en/treaties/african-charter-rights-and-welfare-child.

1. The world bank; Ending Somali Piracy: Go After the System, Not Just the Pirates.

April 11, 2013. https://www.worldbank.org/en/news/feature/2013/04/11/ending-somali-piracy-go-after-thesystem-not-just-the-pirates

2. Otto, L. (2012). Kenya and the Pest of Piracy a Prospective Partner for Peace. [online] Africa Portal. Available at: https://www.africaportal.org/publications/kenya-and-the-pest-of-piracy-a-prospective-partner-forpeace/ [Accessed 23 Oct. 2020].

3. Maritimecyprus (2015). IMO: Djibouti Code of Conduct - Regional agreement on maritime piracy MaritimeCyprus. [online] MaritimeCyprus. Available at: https://www.maritimecyprus.com/2015/11/19/\%EF\%BB\%BF\%EF\%BB\%BFimo-djibuti-code-of-conductregional-agreement-on-maritime-piracy/ [Accessed 23 Oct. 2020].

4. The Africa Center for Strategic Studies. (March 15, 2019). Trends in African Maritime Security. Available from: https://africacenter.org/spotlight/trends-in-african-maritime-security 
attacks at the West Gate and the massacre at Garissa College in Kenya in 2013 and 2015.1

\section{Recommendations}

Somali-piracy had a fatal blow to the Indian Ocean regions and beyond. It is only by successfully working together and exchanging security details concerning pirate hideouts and their activities and Improve maritime surveillance capabilities; it will be challenging to eradicate piracy.

It is essential to approach the Somali political pattern, instability, and unemployment with a determination to find a permanent solution by integrating Somali nationalities both at home and abroad.

\section{Conclusion}

The root causes of Somalia's piracy crisis began with political instability caused by tribal tensions among Somali communities and foreign interventionists who, by illegal fishing and dumping of toxic chemicals, deliberately undermined and violated the region's sovereignty, destroying marine biodiversity. All countries must join hands to take every precautionary measure to ensure that acts of aggression against another sovereign government, cross-border illegal extraction of natural resources, whether on land or at sea, are avoided and that perpetrators face a legal retaliation. It is necessary to remember that a fire can start with a single spark.

In a nutshell, due to its close geographical proximity between Somalia and Kenya, the East African Community has a more significant role to play in resolving the Somali political deadlock and its worsening circumstances, which have engulfed the region in all aspects of life. Somalia's security fragility, an already troubled one, may also affect the neighboring countries of East Africa. Ultimately, empowering and promoting Somalia's weak-central government through political diplomacy and military intervention could help curb piracy and overcome long-standing political turbulence that had existed for decades. Piracy will keep on rising in the Indian Ocean without these multi-dimensional approaches.

1 . BBC News (2017). Who are Somalia's al-Shabab? [online] BBC News. Available at: https://www.bbc.com/news/world-africa-15336689 [Accessed 14 Nov. 2020]. 